\title{
Product Tax Revenue and Economic Growth in Nigeria: An Engle-Granger Approach, Evidence From 1981 - 2019
}

\author{
Henry Ikechukwu Amalu ${ }^{1}$, Thaddeus Nnaemeka Ukwueze ${ }^{2}$, Loenard U. Olife ${ }^{3}$, Favour Friday \\ Irokwe $^{4}$
}

${ }^{I}$ Department of Banking and Finance, University of Nigeria Nsukka, Enugu State, Nigeria

${ }^{2}$ Department of Accountancy, Enugu State Polytechnic, Iwollo, Enugu State, Nigeria

${ }^{3}$ Department of Banking and Finance, Enugu State Polytechnic, Iwollo, Enugu State, Nigeria

${ }^{4}$ Department of Accountancy, Federal Polytechnic Oko, Anambra State, Nigeria

\begin{tabular}{|c|c|}
\hline Article Info & Abstract \\
\hline $\begin{array}{l}\text { Article history: } \\
\text { Received:15 September } 2020 \\
\text { Revised:02 November } 2020 \\
\text { Accepted:04 November } 2020\end{array}$ & $\begin{array}{l}\text { Purpose: Product tax is an essential tool for governments, serving both as a } \\
\text { revenue generator and fiscal policy instrument. The paper examines short-run } \\
\text { and long-run relationships shared by product taxes and economic growth in } \\
\text { Nigeria for the period, } 1981 \text { to } 2019 \text {. }\end{array}$ \\
\hline $\begin{array}{l}\text { Keywords: } \\
\text { Product Tax Revenues, } \\
\text { Economic Growth, } \\
\text { Engle-Granger Approach, } \\
\text { Granger Causality }\end{array}$ & $\begin{array}{l}\text { Approach/Methodology/Design: The study checks the stationarity properties } \\
\text { of the series by testing them for unit roots using Augmented Dickey Fuller } \\
\text { (ADF) method and Philip-Perron unit root test. Both unit root tests indicate } \\
\text { that the series is stationary at first difference. In view of this, the study deploys } \\
\text { a cointegration technique, Engle-Granger two-step procedure to determine } \\
\text { the long-run and short-run links shared by the variables of interest. The Error }\end{array}$ \\
\hline JEL: F43, H70, F63, H83. & $\begin{array}{l}\text { Correction Mechanism (ECM) estimation and the Granger causality } \\
\text { estimations for speed of adjustment and causality of the variables were also } \\
\text { used. }\end{array}$ \\
\hline Paper Type : & $\begin{array}{l}\text { Findings: The results reveal that product tax revenues and economic growth } \\
\text { cointegrate in the long-run; while product tax revenues exert a significant }\end{array}$ \\
\hline Research Article & $\begin{array}{l}\text { positive effect on economic growth both in the short-term and long-term. The } \\
\text { outcome of the Error Correction Mechanism }(E C M) \text { estimation shows a swift }\end{array}$ \\
\hline Corresponding Author: & $\begin{array}{l}\text { speed of adjustment to a new long-run equilibrium after a shock. The outcome } \\
\text { of the Granger causality estimations indicates a uni-directional causality from }\end{array}$ \\
\hline Henry I. Amalu & $\begin{array}{l}\text { economic growth to revenues from product taxes. } \\
\text { Practical Implications: This study is significant at this point when the country }\end{array}$ \\
\hline Email: & $\begin{array}{l}\text { is facing increasing economic challenges. It will be useful to policy makers } \\
\text { who might want to explore the possibility of using product tax as a fiscal }\end{array}$ \\
\hline henryik47@gmail.com & $\begin{array}{l}\text { policy tool, and a source of revenue to augment the declining revenue of the } \\
\text { government from other sources. } \\
\text { Originality/value: The paper explores short-run and long-run relationships } \\
\text { shared between product taxes and economic growth in Nigeria using a two- } \\
\text { step procedure of Engle and Granger, and it verifies causality link between } \\
\text { the later and the former. }\end{array}$ \\
\hline
\end{tabular}

\section{Introduction}

Taxation is a policy instrument used by governments to achieve, majorly, dual objectives-revenue generation and control of the economy as a fiscal policy measure (Eneojo \& Tyokoso, 2014). Supposedly, taxes constitute a substantial source of revenue to governments of most countries. Revenues from taxes are derived from different forms of tax, namely: personal income taxes, corporate taxes, direct taxes, and indirect taxes, among others. Though a good 
number of studies have contributed to the literature on the connection between taxes and economic growth (Alesina et al., 2002; Stoilova, 2017; Xing \& Whalley, 2014; Myles, 2009; Tanchev, 2016); however, a clear cut-link has not been established between the former and the later (Slemrod, 2003). Studies on product tax, a form of indirect tax are grossly inadequate as indicated by the available literature. The literature reviewed however, not exhaustive, shows that clear-cut relationships have not been ascertained by previous studies on the variables of interest as it concerns Nigeria. In light of this, the paper examines the short-run and long-run relationships between product tax revenues and economic growth in Nigeria.

There are opposing schools of thought on the benefit of tax to a nation. Debates are ongoing on whether the imposition of the tax is beneficial to the economy or not. Arguments against taxes hold sway in view of the harmful effects that taxes have on businesses and individuals. Proponents of this view cite the long-term negative impact of tax rates on profits of business firms; which may stifle the performance of business firms especially in an unfavourable business environment as the case in under-developed economies. As well, it may discourage hard work where tax rate is relatively high (Gale \& Samwick, 2016). On the contrary, opponents of this position believe that taxes are inevitable since revenues generated there from are used to 'rubricate' the machinery of government, which ensures law and order and continuity in governance. The need to settle the opposing arguments on tax prompted the initiation of the Laffer curve theory. The theoretical proposition, which is reviewed in section two of this paper, holds that an increase in tax rate becomes harmful after a certain maximum rate is attained. As a developing country facing diverse socio-economic challenges, Nigeria is yet to reap the benefits of an effective tax system.

Taxes are gradually gaining prominence in the federal government's policy schemes on revenue generation. It is not unconnected to the decline in the price of crude oil-the country's major revenue earner. Economic downturns that befell the country in recent times had prompted the government's keen interest in taxes (a major source of internally generated revenue) in order to boost its revenue generation against mounting public expenditures (Deloitte Nigeria, 2017). The adverse economic conditions necessitated the need for a comprehensive national tax policy that the country lacks. The Nigerian tax system in the past years had been poorly structured- faced with challenges such as multiple taxation and double taxation, inter alia. The country encounters difficulty in tax collection and tax law enforcement, a phenomenon experienced in advanced and developing countries alike (Oz-Yalaman, 2019). A new National Tax Policy (NTP) was formally adopted in 2017 to pave way for a more harmonized national policy on tax for governments at both state and federal levels (Richards, 2019).

\section{Literature Review}

Taxes are imposed on individuals and business entities primarily to generate revenue to the governments, among other secondary functions of taxation. Arguments abound on whether increased tax rates are supportive of society's welfare or not. In view of the model employed in his study, Nutahara (2015) opines that a rise in the tax rate, which translates to increased tax revenue (other factors held constant) would not benefit the people, if the tax revenue generated 
produced no utility to households and the business firms. The same effect would be obtained, if increased tax revenue was not converted to government expenditure (Nutahara, 2015). Yanagawa and Uhlig (1996) have proven theoretically that a rise in tax rate (capital tax) can cause an increase in economic growth. Miyazawa and Nutahara (2013) report that boosted tax revenue impacts positively on the economy of Japan in the medium term. Easterly and Rebelo (1993) refute the position that tax rates play much impact on economic growth. They assert that evidence to uphold such view point is increasingly weak. A theoretical proposition that throws more light on the debate is the Laffer curve. The Laffer curve illustrates the relationship between the tax rate and government revenue. The curve, shown in Fig. 1, is hump-shaped with a maximum point that serves as the tip of the curve.

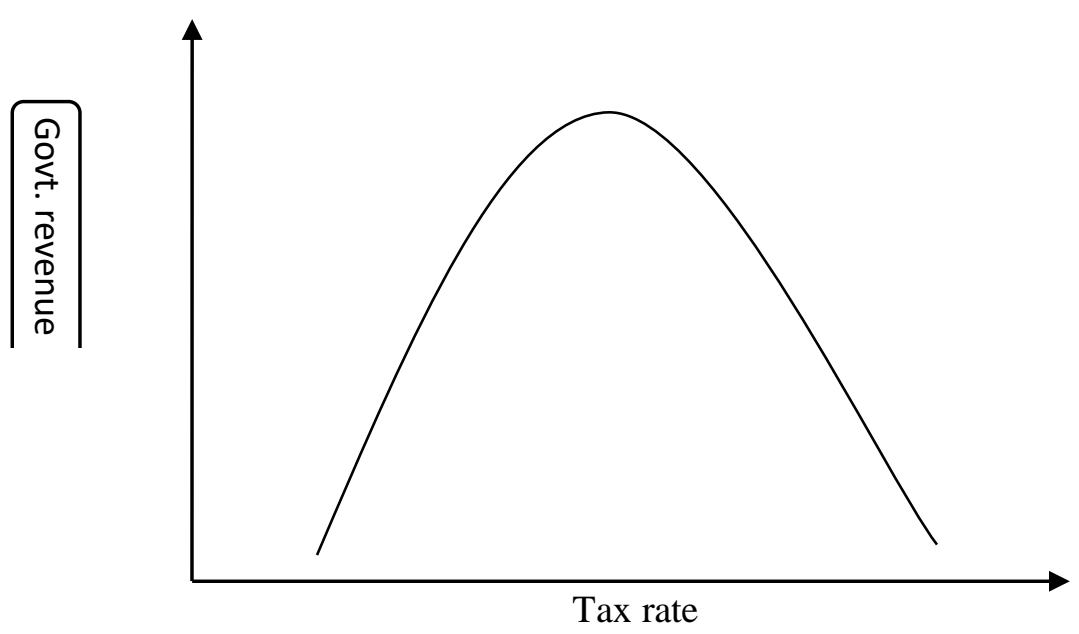

Fig.1: The Laffer curve (Lin and Jia (2019)

Movement of tax rate in-between zero and the specified equilibrium point will either raise government revenue or reduce it. The increasing tax rate will attract more revenue to the government while its reduction will adversely affect it as long as the optimal point is not exceeded (Lin \& Jia, 2019). This position including the case of tax rate beyond a maximum point is clarified by Nutahara (2015). As captured by Nutahara (2015), a rise in the tax rate would have dual opposing impacts-one has direct effect on tax revenue, while the other lessens revenue from tax since a high tax rate discourages investment and incentive to labour supply. Therefore, tax cuts can be used to stimulate the economy, while increasing the tax rate is considered harmful to consumption and investment, and by implication business operations. In response to the debate on the Laffer curve, Bosi and Desmarchelier (2017) posit that in the longterm the conditions surrounding a Laffer curve and a green paradox are exclusive. Malcomson (1986) believes that certain properties of Laffer curve may not apply under a simple general equilibrium model. The empirical reviews carried out in this study are presented thus.

Aghion et al. (2016) find the impact of taxation on growth and innovation to be U-shaped and increasing, and greater local corruption weakens the direct effect of taxation on growth and innovation. Y1lmaz (2013) finds that taxes have a concave-shaped effect on growth rate as a result of the positive effect of the subsidy on the research sector and inverse effect on the portion 
of labour allotted to the research sector. Furthermore, it establishes that the probability of a positive effect of an increased tax on output growth rises as competition in the economy becomes stronger. Stoilova (2017) carries out a panel study on the nexus between tax structure and economic growth in the European Union 28 member states for the period from 1996 to 2013, and finds that economic growth is boosted by tax structure. Lin and Jia (2019) investigate the link between tax rate (direct tax on earnings from labour) and revenue of government and economic performance in China from the perspective of the Laffer curve using the model, Computable General Equilibrium (CGE). The paper posits that tax cuts will have a positive impact on government revenue and economic growth if the top of the Laffer curve has been attained. Using an endogenous growth model, Ihori (2001) examines the effect of wealth taxation on economic growth and finds that a rise in taxes on life cycle savings will cause a decrease in intragenerational growth differences of human capital formation. Chen, Chu, Chu, and Lai (2017) check the short-run and long-run impacts of capital taxation on innovation and economic growth. And the results show that a rise in the capital income tax exerts a positive taxshifting effect and a negative consumption effect on innovation and economic growth. The study holds that an increase in the capital tax rate has a positive impact on the continuous equilibrium growth due to the fact that the positive tax-shifting effect exceeds the negative consumption effect. Asaolu et al. (2018) explore the association between tax revenue and economic growth in Nigeria for the period 1994 to 2015. The paper employs tax proxies as Company Income Tax (CIT), Value Added Tax (VAT), Petroleum Profit Tax (PPT), and Custom and Excise Duties (CED). The study's empirical results show that CED, VAT, and PPT exert a positive and significant effect on economic growth in Nigeria; however, CIT has an inverse relationship with output growth, though insignificant.

\section{Methodology and Procedures}

The study explores short-run and long-run relationships between product taxes and economic growth in Nigeria using a two-step procedure of Engle and Granger (E-G) approach. The EngleGranger residual-based approach as developed by Engle and Granger (1987) is applied when the model variables are all integrated of order one. For the study, the gross domestic product (GDP) serves as the proxy for the dependent variable (economic growth), while the independent variable (tax revenues) is uncoupled into two proxies, namely: tax revenue and tax to GDP ratio.

The steps of residual-based Engle-Granger method are specified below:

The initial step involves ascertaining the stationarity properties of the variables via a unit root test to ensure that they are integrated of the same order. In other words, the variables of interest should be integrated of the first order. Where this becomes the case, the cointegration method can be deployed to determine the series' long-run relationship. We adopt both the ADF and Philip-Peron (PP) unit root tests to establish the stationarity properties of the datasets. The ADF unit root procedure as proposed by Dickey \& Fuller (1979) is presented as follows:

$$
\Delta \mathrm{Y}_{\mathrm{t}}=\alpha_{0}+\beta_{\mathrm{t}}+\alpha_{1} \mathrm{Y}_{\mathrm{t}-1}+\Sigma \mathrm{b} 1 \Delta \mathrm{Y}_{\mathrm{t}-1}+\varepsilon_{\mathrm{t}}
$$


The ADF null hypothesis is established where $Y_{t}$ contains a unit root, meaning that $\alpha_{1}=1$. The alternate is held if $\alpha_{1}<1$ meaning that the series has no unit roots. Reject the null hypothesis if ADF tau value is greater than the calculated absolute value of $\alpha_{1}$, which indicates that $Y_{t}$ has no unit roots otherwise do not reject the null hypothesis (Dickey and Fuller, 1981).

We employ the Phillips-Perron (PP) unit root test (Phillips \& Perron, 1988) to reinforce the evidences of the series' stationarity properties as first determined via the ADF test. Having established that the datasets are integrated of order one I (1), we proceed to estimate regression on the level series using the Classical Linear Regression Model (CLRM) after which the regression residuals are saved. The CLRM procedure is stated below:

$$
\mathrm{GDP}=\beta_{0}+\beta_{1} \mathrm{TX}+\beta_{2} \mathrm{TX}-\mathrm{GDP}+\mathrm{U}_{\mathrm{t}} \quad \text { eq.2 }
$$

For long-run relationship to be established among the variables, TX, TX-GDP and GDP, the estimated residual in eq. 2 should be stationary, i.e., $\mu \mathrm{t} \sim 1(0)$. In other words, a proof in favour of cointegration exists, if the null hypothesis of the residual-based unit root test is rejected (Engle and Granger, 1987). We adopt the PP method to ascertain whether the residual series in eq. 2 is stationary or not. The model for the residual-based unit root test is presented below:

$$
\Delta \mu_{\mathrm{t}}=\alpha_{1} \mu_{\mathrm{t}-1}+\varepsilon_{\mathrm{t}}
$$

where, $\varepsilon_{\mathrm{t}}$ denotes the errors derived from the estimated regression; $\mu_{\mathrm{t}-1}$ represents the lagged residuals; $\alpha_{1}$ is the parameter for the slope of the line; and $\Delta \mu_{\mathrm{t}}$ stands for the first differenced residual. The next step is concerned about estimating the Error Correction Mechanism (ECM) using the ordinary least square (OLS). The ECM, a differenced model, is used to model both short-run and long-run relations together. The ECM is premised on the assumption that more than one series show equilibrium relation that decides the behaviour of both long-term and short term. ECM connects the model variables where they are found to cointegrate. The ECM model is presented thus:

$$
\Delta \mathrm{GDP}=\alpha_{0}+\alpha_{1} \Delta \mathrm{TX}+\alpha_{2} \Delta \mathrm{TX}-\mathrm{GDP}+\alpha_{3} \mu_{\mathrm{t}-1}
$$

where $\Delta$ represents the first difference operator; $\alpha_{1}$ and $\alpha_{2}$ refer to the coefficients of the parameters; while $\alpha_{3}$ indicates the error correction term lagged one period. Furthermore, $\alpha_{1}$ and $\alpha_{2}$ represent the short-term impacts of the explanatory variables on the explained variable, GDP. The coefficient represented by $\alpha_{3}$ is expected to be significant and negatively signed. It denotes the speed of adjustment of the variables towards a new long-run equilibrium after a shock. The coefficient $\alpha_{3}$ tending to -1 is an indication of a fast speed of adjustment, while a movement towards 0 signifies a slow speed of adjustment.

The datasets applied in the study are annual series that span 39 years, $1981-2019$ obtained from the Statistical Bulletin of the Central Bank of Nigeria (CBN) and the World Development Indicators (WDI). The beginning period corresponds with the date the CBN started to keep records of some economic indicators such as the gross domestic product (GDP). And the ending date (2019) is adopted to reflect the behaviour of the economy in recent times. The paper adopts 
product tax revenues and tax to GDP ratio as proxies for tax, while the Gross Domestic Product (GDP) is a proxy for economic growth in Nigeria. The variables of the study are briefly explained below.

Table 1: Descriptive Statistics

\begin{tabular}{llllll}
\hline Variables & Mean & Median & Std. deviation & Minimum & Maximum \\
\hline GDP & 30559.51 & 6897.48 & 41655.36 & 144.83 & 144210.50 \\
TX & 298.30 & 72.13 & 437.34 & 1.38 & 1428.65 \\
TX-GDP & 0.01 & 0.01 & 0.00 & 0.00 & 0.01 \\
\hline
\end{tabular}

Source: Authors' computation

Tax: the series represents product tax revenues for the period under review. The values are net taxes on products. In other words, they represent the addition of product taxes excluding subsidies. Product taxes are imposed on the production of goods and services, sale and purchase of goods and services or use of the goods and services, which are payable by producers. Government grant subsidies on such goods and services to reduce production cost hence maintain price stability on them.

Tax to GDP ratio: The series is derived from both the tax revenues described above and the gross domestic product (GDP). It represents the tax revenue relative to the economy of Nigeria as measured by the GDP. That is, a portion of the Nigeria's GDP contributed by product taxes.

Gross Domestic Product: the time-series is a representation of the total value of all goods and services produced in Nigeria within a fiscal year.

Table 2: Unit Root Estimations

\begin{tabular}{|c|c|c|c|c|c|c|c|c|}
\hline \multirow[t]{2}{*}{ Variables } & \multicolumn{4}{|c|}{ ADF Test } & \multicolumn{4}{|c|}{ PP Test } \\
\hline & $\begin{array}{c}\text { ADF t- } \\
\text { stat }\end{array}$ & Critica & Values & $\begin{array}{l}\text { Order of } \\
\text { Int. }\end{array}$ & $\begin{array}{l}\text { PP t - } \\
\text { stat }\end{array}$ & Critica & Values & $\begin{array}{c}\text { Order of } \\
\text { Int. }\end{array}$ \\
\hline InGDP & -3.21 & $-2.94 * *$ & -3.62 & 1 & -3.12 & $-2.94 * *$ & -3.62 & 1 \\
\hline InTX & -5.80 & $-2.95 * *$ & $-3.63 *$ & 1 & -6.77 & $-2.94 * *$ & $-3.62 *$ & 1 \\
\hline TX-GDP & -5.84 & $-2.95 * *$ & $-3.63 *$ & 1 & -9.26 & $-2.94 * *$ & $-3.62 *$ & 1 \\
\hline
\end{tabular}

Note: $(1) *$ and $* *$ indicate statistical significance at $1 \%$ and $5 \%$ level respectively; (2) the lag lengths for InGDP, InTAX, and TX-GDP under the ADF test are 0, 1, and 1 respectively; (3) the equations for both ADF and PP tests are for intercept only; (4) the PP test is estimated based on Bartlett kernel with the support of Newey-West bandwidth.

\section{Results and Discussion}

As regards the normality of the datasets, the assumption of the JB statistics is rejected (JarqueBera, 1980). The use of the data in this study for estimations is not affected, notwithstanding. The base-level series for the study are positively skewed (i.e., leptokurtic) except the scaled variable that is skewed negatively.

Table 3: Residual-Based PP Test Results

\begin{tabular}{lccc}
\hline Variable & \multicolumn{2}{c}{ Critical values } & t-Statistic \\
\hline & $5 \%$ & $1 \%$ & \\
Residuals & $-2.94^{* *}$ & $-3.62^{*}$ & -5.83 \\
\hline
\end{tabular}


Source: Authors' computation

Note: * and ** indicate statistical significance at $1 \%$ and $5 \%$ levels respectively

The unit root test results indicate that all the time-series are integrated of the first order at 5\% level of significance from both the ADF and PP methods. At first difference, the null hypothesis of the presence of unit roots in the datasets is rejected with the critical values (in absolute terms) being less than the absolute values of the t-statistic. This is the case in the two-unit root tests. In addition, InTX and TX-GDP exhibit stationarity at first difference at $1 \%$ level of significance, as reported by both the ADF and PP tests. The time-series are deployed for the two-step procedure of E-G approach, having confirmed their stationarity at first difference. Then, the residual-based long-run test is estimated.

The outcome of the residual-based unit root test shows the residuals series is stationary at level as indicated in Table 3. The residual series is stationary at $1 \%$ and 5\% significance respectively, indicating evidence of long-run relationships. This position is corroborated by the ECM tests, which generally show short-run and long-run relations.

Table 4: ECM Estimations

\begin{tabular}{lcccc}
\hline Variable & Coefficient & Std. Error & t-Stat & P-value \\
\hline C & 0.03 & 0.01 & 2.09 & 0.04 \\
AnTX & 0.85 & 0.07 & 12.66 & 0.00 \\
ATX-GDP & -174.87 & 14.17 & -12.34 & 0.00 \\
ECT (-1) & -0.91 & 0.15 & -6.20 & 0.00 \\
R-square & 0.85 & & & \\
Adj. R-squ & 0.82 & & & \\
F-stat & 55.50 & & \\
Source: Authors' computation & & &
\end{tabular}

The ECM results reported in Table 4 validate evidence of long-run relationship between product tax revenues and economic growth in Nigeria. The results show the model in eq.4 as a strong good fit as reported by the values of the $\mathrm{R}^{2}$ and Adjusted $\mathrm{R}^{2}$, respectively. The error correction term (ECT) coefficient reported in Table 4 is statistically significant at 5\% level, and correctly signed. The ECT coefficient of -0.91 suggests a swift speed of convergence to long-run equilibrium after a shock. It follows that deviations in the relationships between the variables will take about one year to adjust to long-run equilibrium. The ECM result in Table 4, in addition, shows vital information about short-run relations between product tax revenues and economic growth in Nigeria. The short-run coefficient of tax revenues with a value of 0.85 is statistically significant at $5 \%$ level. Also, the value indicates statistical evidence for a direct relationship between product tax revenues and economic growth in Nigeria. This implies that 1 percent increase in product tax revenue will increase economic growth by 0.85 percent. With reference to the results from the Dynamic Least Squares (DOLS) estimations shown in Table 5, InTX indicates a positive coefficient of 1.07 and p-value 0.00 that is statistically significant at 0.05 thresholds. We deduce, therefore, that product tax revenues exert a long-run positive impact on economic growth in Nigeria. Pair-wise Granger causality estimation results presented in 
Table 6 show a uni-directional causality from economic growth to revenues from product taxes at $5 \%$ level of significance. In view of the result, a change in economic output will induce changes to tax revenue.

Table 5: Long-run Estimation Results from DOLS

\begin{tabular}{lcccc}
\hline Variable & Coefficient & Std. Error & t-Stat & P-value \\
\hline C & -15.67 & 0.33 & -48.03 & 0.00 \\
InTX & 1.07 & 0.02 & 63.98 & 0.00 \\
TX-GDP & -195.70 & 2.41 & -81.16 & 0.00 \\
\hline
\end{tabular}

Source: Authors' computation

\section{Discussion}

The results of paper reveal that product tax revenues and economic growth in Nigeria share cointegrating relationships. We find that revenues from net product taxes exert a positive and significant effect on national output growth in the short-term and long-term respectively. Corroborating the evidence of a long-run relationship shared between the variables is the error term mechanism outcome, which indicates that 91 percent of the deviations in the system are corrected annually. It suggests that a new equilibrium long-run relationship is established swiftly after a shock. The findings agree with the results of Stoilova (2017) which show that economic growth is encouraged by taxation. From a policy perspective, the federal government can relatively raise product taxes to generate more revenue to meet shortfalls in revenue generation. Policy makers can also deploy product taxes as a fiscal policy tool to correct the production decline in the real sector of the economy. This is important in view of the finding that 1 per cent increase in product tax will increase output by 0.85 per cent.

The outcome of a causality test shows a unidirectional causality between economic output and revenues from the indirect tax. It suggests that a unit change in economic output will induce changes in product tax revenue. This implies that the performance of the economy in terms of output creation affects the amount of money generated from product taxes. In other words, increased economic productivity will bring about more revenue from product taxes since a positive relationship exists between product tax revenues and output growth, as established by this study. The policy implication of this finding is that the government should invest more in infrastructural development that will create an economic environment conducive to business activities to thrive. Such a policy thrust should encourage production in various sectors of the economy especially the manufacturing sector. The government can as well raise its revenue from product taxes by using a progressive tax policy on imported goods, or increase taxes on nonessential imported goods. This will help to protect the local industries and support them to operate more successfully in the business environment.

Table 6: Pair-wise Granger Causality

\begin{tabular}{llc}
\hline \multicolumn{1}{c}{ Null Hypothesis } & F-Stat & P-value \\
\hline InTX does not Granger Cause InGDP & 0.079 & 0.97 \\
InGDP does not Granger Cause InTX & 3.60 & $0.03^{* *}$ \\
TX-GDP does not Granger Cause & & \\
InGDP & 0.09 & 0.96 \\
\hline
\end{tabular}




\begin{tabular}{lcc}
\hline InGDP does not Granger Cause TX- & & \\
GDP & 0.14 & 0.94 \\
TX-GDP does not Granger Cause & & 0.06 \\
InTX & 2.78 & 0.93 \\
InTX does not Granger Cause TX- & 0.15 & \\
GDP & \\
$\quad$ Source: Authors' computation & Note: the selected lag strength is 3; ** denotes statistical significance at 5\%.
\end{tabular}

\section{Conclusion and Suggestion}

The paper explores short-run and long-run relationships shared between product taxes and economic growth in Nigeria using a two-step procedure of Engle and Granger, and it verifies causality link between the later and the former. Following the results of the analysis conducted, we establish a long-run relationship between product taxes and output growth in Nigeria. Inter alia, we find that product taxes exhibit strong positive impact on economic growth in Nigeria both in the long-run and short-run. Sequel to the findings of the study, we recommend that the government generate substantial funds from product taxes. Taxes imposed on imported goods (especially non-essential goods and goods with local substitutes) can constitute a bulk of the revenues. Such funds should be invested in the provision of public goods that aid operations of the manufacturing firms in the economy. More funding should be given to the key sectors of the economy such as the power sector, security sector, education (Research \& Development), among others; to help create a more friendly business environment. This is in view of the finding that a change in productivity induces changes in product tax revenues.

\section{Acknowledgements}

We appreciate two anonymous referees for their comments and suggestions.

\section{Conflict of interests}

The authors declare no conflict of interest.

\section{Funding}

This study was not funded by any institution. The expenses incurred in the course of the research study were from the authors.

\section{References}

Aghion, P., Akcigit, U., Cagé, J., \& Kerr, W. R. (2016). Taxation, corruption, and growth. European Economic Review, 86, 24-51.

Alesina, A., Ardagna, S., Perotti, R., \& Schiantarelli, F. (2002). Fiscal policy profits and investment. American Economic Review, 92, 571-589.

Chen, P., Chu, A. C., Chu, H., \& Lai, C. (2017). Short-run and long-run effects of capital taxation on innovation and economic growth. Journal of Macroeconomics. doi: 10.1016/j.jmacro.2017.07.002

Dickey, D.A. \& Fuller, W.A. (1981). Likelihood ratio statistics for autoregressive time series 
with a unit root, Econometrica, 49.

Deloitte Nigeria. (2017). Nigeria: Increasing tax revenue: Is a new approach required?

Retrieved from https://www.mondaq.com/nigeria/tax-authorities/571840/increasing-taxrevenue-is-a-new-approach-required

Ehrhart, H., Minea, A., \& Villieu, P. (2014). Debt, seigniorage, and the growth Laffer curve in developing countries. Journal of Macroeconomics, 42, 199-210. doi:10.1016/ j.jmacro 2014.07.004.

Eneojo, S. \& Tyokoso, G. (2014). Taxation and revenue generation: An empirical investigation of selected states in Nigeria. Journal of Poverty, Investment and Development, 4.

Gale, W. G., \& Samwick, A. A. (2016). Effects of income tax changes on economic growth. Brookings Institution and Tax Policy Center.

Ihori, T. (2001). Wealth taxation and economic growth. Journal of Public Economics, 79, 129 148.

Jarque, C.M., \& Bera, K. (1980).Efficient tests for normality, homoscedasticity and serial dependence of regression residuals. Economic Letters, 6, 255-259.

Lin, B., \& Jia, Z. (2019). Tax rate, government revenue and economic performance: A perspective of Laffer curve. China Economic Review, 56.

Miyazawa, K., \& Nutahara, K. (2013). Dynamic effects of fiscal policy shock in Japan:

Evidence from a structural VAR with sign restrictions. CIGS Workig Paper 13-006E.

Myles, G. (2009). Economic growth and the role of taxation - aggregate data. OECD Economics Department Working Papers No. 714.

Nutahara, K. (2015). Laffer curves in Japan. Journal of the Japanese and International Economies, 36, 56-72. doi:10.1016/j.jjie.2015.02.002.

Oz-Yalaman, G. (2019). Financial inclusion and tax revenue. Central Bank Review, 19, 107-113.

Phillips, P.C. \& Perron, P. (1988). Testing for a unit root in time series regression. Biometrika, 75 (2), 335-346.

Richard, N. (2019). Overview of the national tax policy and its implication for tax administration in Nigeria. NAUJILJ, 10 (2).

Slemrod, J. (2003). More tax cuts? The truth about taxes and economic growth. Challenge, 46, 5-14.

Stoilova, D. (2017). Tax structure and economic growth: Evidence from the European Union. Contaduría y Administración. doi: 10.1016/j.cya.2017.04.006.

Tanchev, S. (2016). The role of the proportional income tax on economic growth of Bulgaria. Ikonomi cheski Izsledvania, 25(4), 66-77.

Xing, W., \& Whalley, J. (2014). The golden tax project, value-added tax statistics, and the analysis of internal trade in China. China Economic Review, 30, 448-458. doi:

10.1016/j.chieco. 2014.05.005.

Yanagawa, N., \& Uhlig, H. (1996). Increasing the capital income tax may lead to faster growth. Eur. Econ. Rev. 40, 1521-1540.

Y1lmaz, E. (2013). Competition, taxation and economic growth. Economic Modelling, 35, 134139. 
GDP

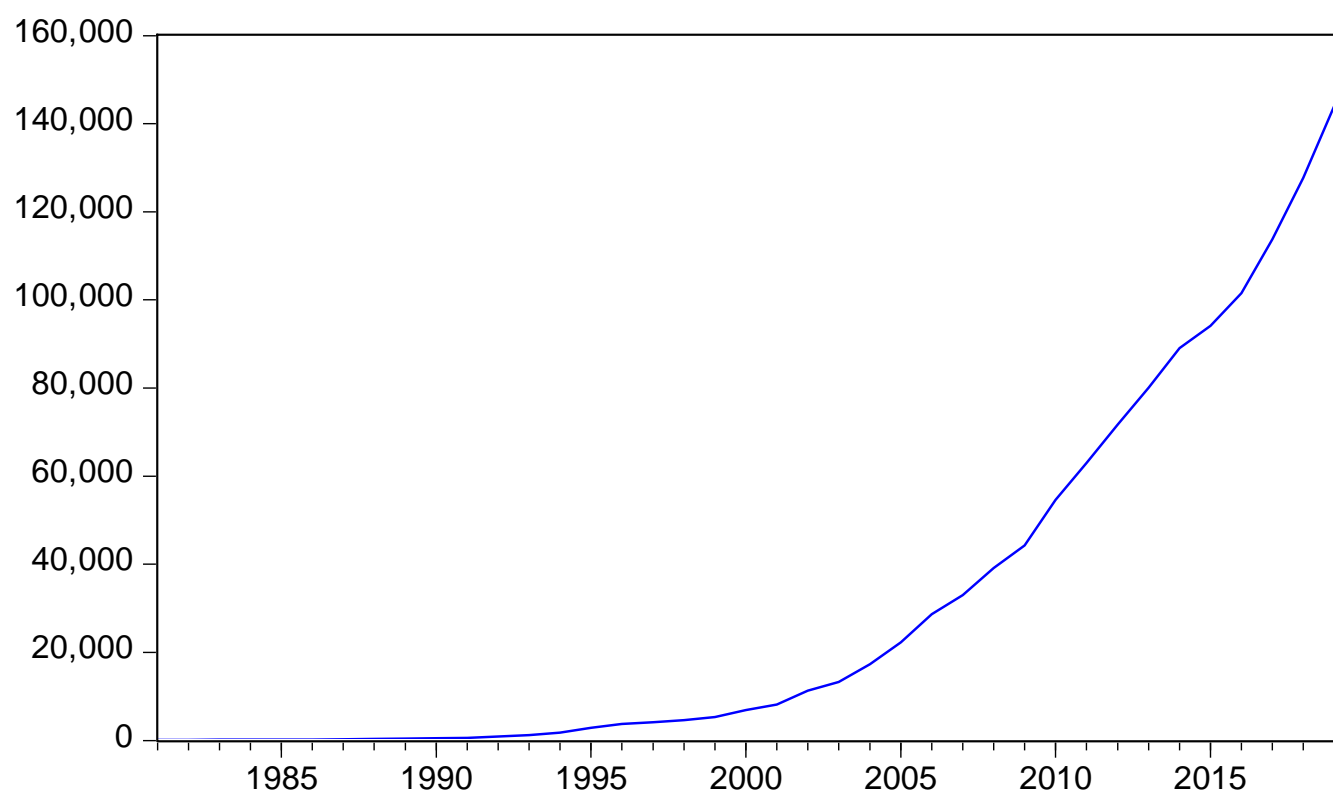

$\operatorname{Tax} \operatorname{Rev}$

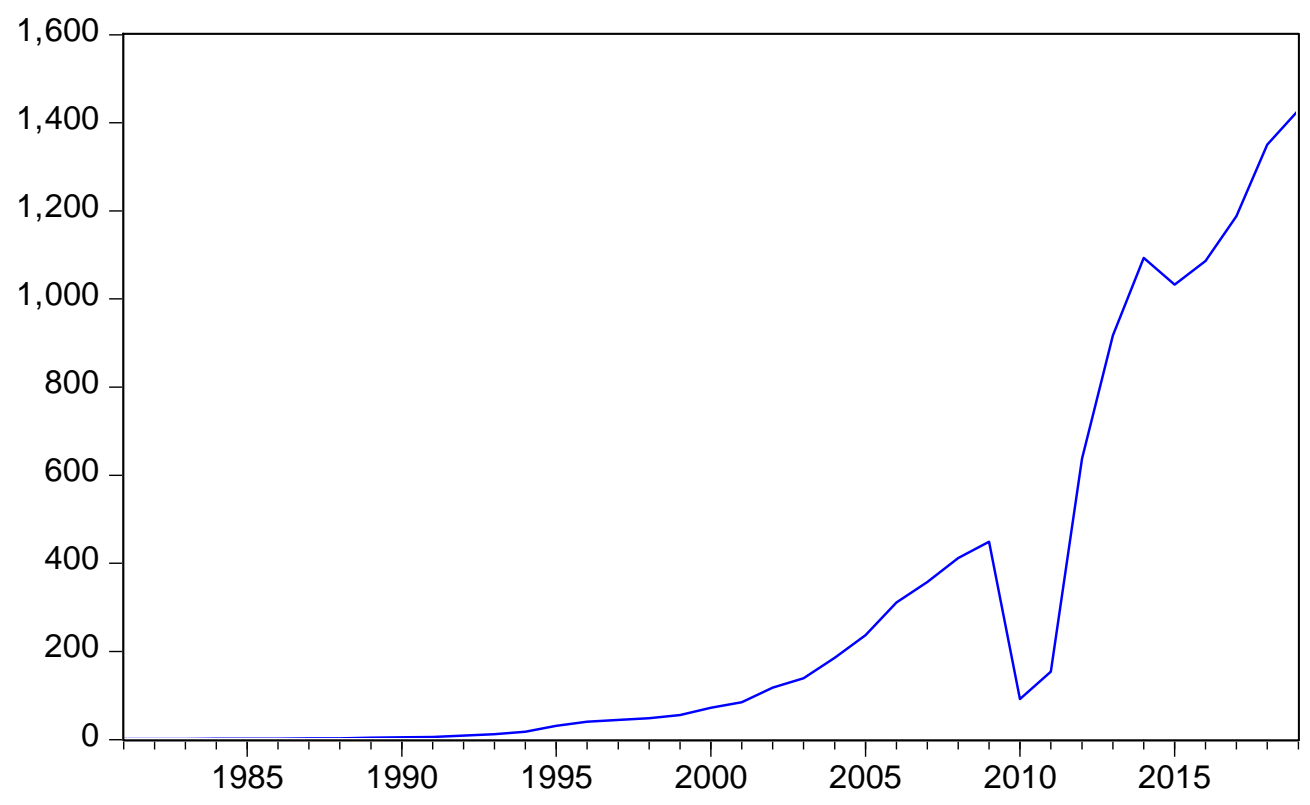

